\title{
GEOGRAPHICAL DISTRIBUTION AND POPULATION STRUCTURE OF SPRINGBOK ANTIDORCAS MARSUPIALIS RUMEN PROTOZOA IN SOUTHERN AFRICA
}

\author{
R. C. WILKINSON and W. VAN HOVEN \\ Mammal Research Institute \\ Department of Zoology \\ University of Pretoria \\ Pretoria \\ 0002
}

Abstract - Springbok were sampled in Angola, South West Africa, Kalahari Gemsbok National Park, the Cape Province and Eastern Transvaal between July 1973 and July 1974. All the ciliates found in the 20 rumens investigated belonged to a single genus Entodinium (family Ophryoscolecidae) and they varied in number from $0,3 \times 10^{6}$ to $2,5 \times 10^{6}$ per $\mathrm{cm}^{3}$ of rumen fluid. The different species were found and a positive correlation is seen between total numbers and protein content of the feed. It has been concluded that the numbers of $E$. parvum are closely related to the protein concentration of the feed.

\section{Introduction}

Very little information is available on the ciliate fauna of wild ruminants residing in southern Africa. Since nothing is known in this respect from the springbok a series of rumen samples were collected in Angola, South West Africa, the Kalahari Gemsbok National Park, the Cape Province and Eastern Transvaal between July 1973 and July 1974.

The intention of this investigation was to obtain quantitative and qualitative (taxonomic) information about the rumen ciliate fauna of springbok living under natural conditions. The taxonomic results and descriptions of two new species has been submitted for publication separately. All the ciliates found in the 20 rumens investigated from the different geographical areas, belonged to a single genus Entodinium (family Ophryoscolecidae). This is unique since the only other ruminants that have ever been found to show an Entodinium - only rumen fauna, are the Alaskan moose Alces americana (Dehority 1974) and the whitetailed deer of Texas Odocoileus virginianus (Pearson 1965). The situation in the moose is uncertain since Dogiel (1927) found three other genera in its rumen as well. Ruminants in general usually contain 8-12 genera 
and a large number of different species that vary from simple types such as the entodinia to large anatomically complicated specimens such as has been found in the tsessebe Damaliscus lunatus lunatus from Northern Transvaal (van Hoven 1975).

The 10 different species are listed in Table 2. The two species Entodinium kalaharicus and $E$. lucii were found for the first time in the springbok whilst E. fyferi (van Hoven 1975) was described from the South African tsessebe.

An attempt is further made to relate the ciliate data to the nutritional composition of the feed, the geographical distribution and other facts known about the ecology of the host animal.

\section{Material and Methods}

The methods of collecting the material and the staining of the protozoa is described in van Hoven (1974).

Extraction and counting of the ciliates was done by first washing the rumen fluid samples through fine-meshed sieves of 16 and $44 \mathrm{~cm}^{1}$ with $100 \mathrm{~cm}^{3}$ of water whilst being agitated with a fine paint brush. The resultant fluid was thoroughly shaken up and $1 \mathrm{~cm}^{2}$ of it was diluted with $10 \mathrm{~cm}^{3}$ of water. To revent rapid settling of the organisms and to facilitate even dispersal in the counting chamber $1,25 \mathrm{~cm}^{3}$ of glycerine was added. This mixture was well shaken up and a small quantity of it placed in a McMaster counting chamber to determine the total number of ciliates present. Counts were done at $160 \times$ magnification, four from each sample and the average of these was used in determining the numbers per cubic centimeter.

For population structure determination random distribution on a slide was assumed because the sample of rumen fluid was shaken up well immediately before a few drops were spread on the surface.

Part of the solid digesta was collected and sun dried. These were later analysed for starch, nitrogen, protein, fibre and ash.

Hosts and Regions sampled:

1. Samples 1, 2 and 3 were obtained from springbok shot in the district of Karasburg in southern South West Africa on 1973.06.08 and 1973.06.09. The vegetation in this area is desert-like with scattered clumps of grass and shrubs.

2. Samples 4, 5 and 6 were obtained from springbok shot in the Mocamedes district of Angola on 1973.07.03. The vegetation is similar to the above.

3. Samples 7 to 16 were obtained from springbok shot in the Kalahari Gemsbok National Park on 1974.04.16. The vegetation is savanna in the cases of animals 7 to 12 and open grassland for 13 to 16 . 
4. Samples 17, 18 and 19 were obtained from the Ermelo district of the Transvaal. The animals were shot on 1974.06.16. The vegetation in this area is open grassland.

5. Sample 20 was from a springbok shot near Graaff Reinet in the Cape Province on 1974.07.17.

Results

\section{Total Numbers}

A considerable amount of variation was evident between the samples with regard to the total number of ciliate protozoa per $\mathrm{cm}^{3}$ original rumen fluid counted. The number of cells varied from 301300 in sample 19 to 2425100 in sample 12 .

Table 1

Total number of ciliate protozoa found in the springbok from the different areas sampled

\begin{tabular}{|c|c|c|}
\hline Area & Sample Number & Total count $/ \mathrm{ml}$ \\
\hline Karasburg, S.W.A. & $\begin{array}{l}1 \\
2 \\
3\end{array}$ & $\begin{array}{lll}1 & 501 & 920 \\
1 & 118 & 820 \\
1 & 256 & 220\end{array}$ \\
\hline Mocamedes, Angola & $\begin{array}{l}4 \\
5 \\
6\end{array}$ & $\begin{array}{lll}1 & 891 & 080 \\
5 & 836 & 800 \\
1 & 791 & 240\end{array}$ \\
\hline $\begin{array}{l}\text { Kalahari Gemsbok } \\
\text { National Park, } \\
\text { R.S.A. }\end{array}$ & $\begin{array}{r}7 \\
8 \\
9 \\
10 \\
11 \\
12 \\
13 \\
14 \\
15 \\
16\end{array}$ & $\begin{array}{llll}1 & 171 & 620 \\
1 & 094 & 580 \\
2 & 138 & 160 \\
1 & 860 & 480 \\
1 & 683 & 120 \\
2 & 425 & 080 \\
2 & 172 & 120 \\
9 & 672 & 600 \\
1 & 949 & 400 \\
1 & 625 & 940\end{array}$ \\
\hline Ermelo, R.S.A. & $\begin{array}{l}17 \\
18 \\
19\end{array}$ & $\begin{array}{lll}4 & 52 & 280 \\
9 & 60 & 120 \\
3 & 01 & 380\end{array}$ \\
\hline Graaff Reinet & 20 & 2429040 \\
\hline
\end{tabular}


There is evidence to prove that the numbers of cells in the rumen vary significantly with the seasons (Westerling 1970; Pearson 1965). This would, however, not appear to be the reason for the above mentioned discrepancy as these two samples were obtained within a month of each other.

Food composition as a factor influencing cell numbers has been found to be very important by a number of workers (Westerling 1970). This is a more feasible explanation for the variations found in this study because the above extremes are samples from different areas having different vegetation types.

There is a similarity in total numbers between animals from the same area which is not necessarily evident between areas. All animals sampled from the Ermelo district had considerable lower numbers of entodinia than those from other areas. This indication that areas, i.e. vegetation types, influence the protozoan population will be expanded on in the section on food composition. Total counts for each animal sampled are given in.Table 1.

\section{Population Composition}

The population composition of ciliate protozoa found in ruminants varies considerably both on the interspecific and intraspecific levels.

In all the springbok examined, cases were found of one or more species totally lacking or represented by only a few individuals. This is despite the fact that other animals from the same area may show large numbers of the same species in their rumen populations. According to Westerling (1970) a ciliate species, which commonly occurs in the rumen of a certain host, may occasionally be lacking in some individuals in the herd. This phenomenon may depend on chance or on actual fluctuations in the numbers of the species involved. It can be assumed that competition or other ecological factors at times cause the disappearance of some species from the rumen fauna and that re-inoculation from other host individuals in the herd, or a change in the biotope before the species is exterminated, enable the species to reattain normal numbers. The interval can be looked on as a period when this particular species is not adapted to the biotope.

The most important factor in the ciliate population structure in the rumen of the springbok is that, as was found in the white-tailed deer (Pearson 1965) and the Alaskan moose (Dehority 1974), only the genus Entodinium of the family Ophryoscolecidae was represented.

The percentage representation of the different species is given in Table 2 and Fig. 1. From this it can be seen that $E$. parvum is the dominant species in all the populations with the exception of two animals from the Kalahari where E. kalaharicus n. sp. dominated (Samples 11 and 13). An interesting characteristic of these population structures is that, al- 

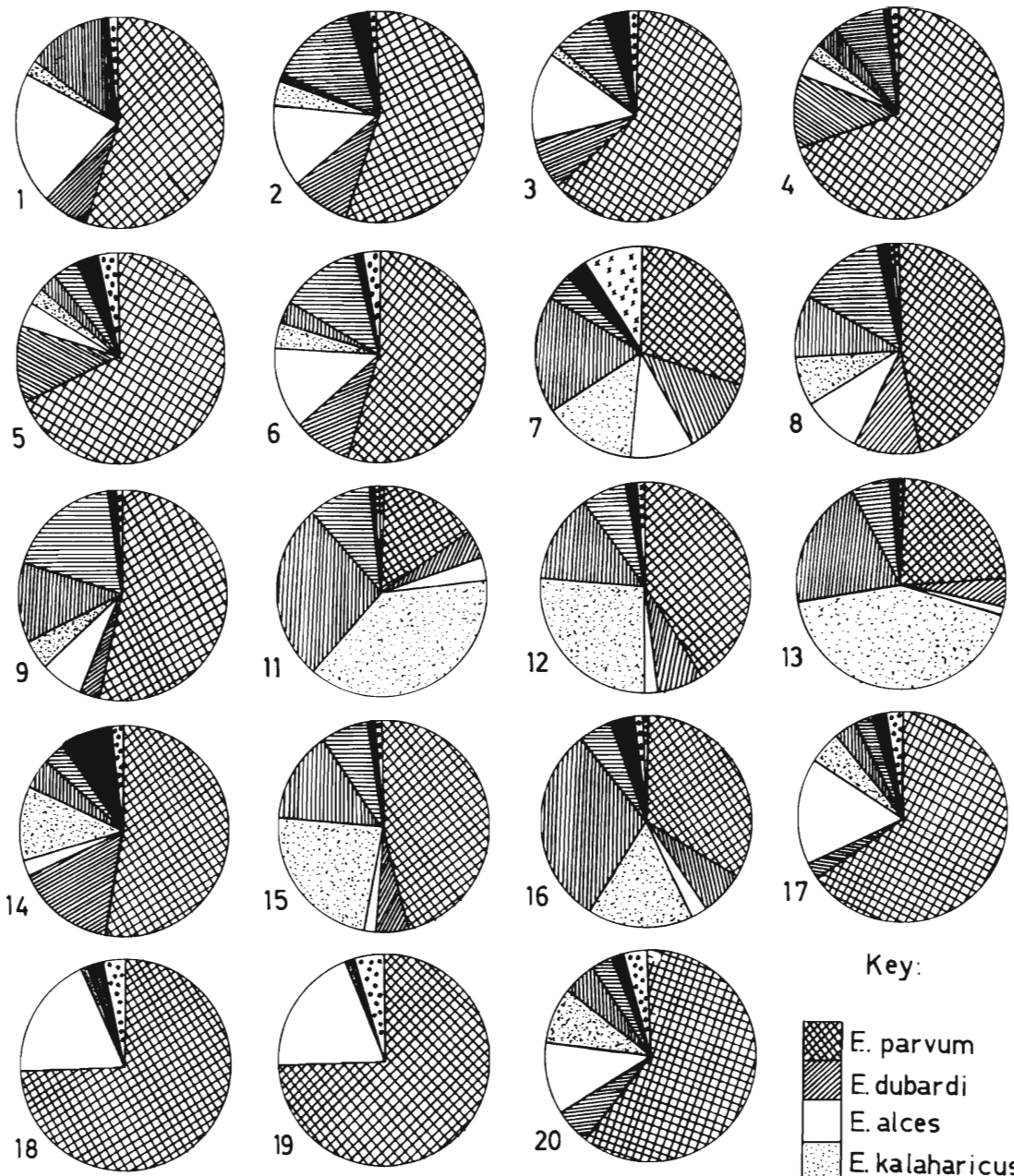

FIG. 1: Population Composition of the Rumen Ciliate Fauna of Each Sample/

Key:

E. parvum
E. dubardi
E. alces
E. kalaharicus
E. caudatum
E.lucii
E.anteronucleatum
$\therefore:$ E. fyferi
$\therefore:$ E. bovis
E.longinucleatum

Fig. 1. Population composition of the rumen ciliate fauna of each sample.

though some of the less numerous species are sometimes absent trom a sample, the composition of each population is relatively constant, regardless of geographical area.

The different areas studied showed different degrees of domination by $E$. parvum and a variation in the species which are sub-dominate (Table 3). 
Table 2

Percentage of total ciliate population of each Entodinium as found in all the springbok sampled

Ciliate

Sample Number

(Entodinium)

\begin{tabular}{|c|c|c|c|c|c|c|c|c|c|c|c|c|c|c|c|c|c|c|c|c|}
\hline & 1 & 2 & 3 & 4 & 5 & 6 & 7 & 8 & 9 & 10 & 11 & 12 & 13 & 14 & 15 & 16 & 17 & 18 & 19 & 20 \\
\hline E. parvum & 54,9 & 54,5 & 63,3 & 70,0 & 68,3 & 55,2 & 30,0 & 47,5 & 53,7 & - & 15,2 & 40,6 & 23,3 & 52,8 & 46,3 & 34,0 & 65,6 & 73,9 & 74,9 & 60,9 \\
\hline $\begin{array}{r}\text { E. dubardif. } \\
\text { dubardi }\end{array}$ & 6,6 & 9,3 & 7,9 & 11,2 & 12,3 & 8,4 & 11,6 & 9,6 & 2,8 & - & 4,9 & 7,2 & 4,3 & 16,1 & 5,3 & 6,2 & 2,8 & - & - & 5,1 \\
\hline E. alces & 20,9 & 12,6 & 13,8 & 2,8 & 3,7 & 12,6 & 9,4 & 9,6 & 6,9 & - & 3,2 & 1,4 & 0,4 & 2,3 & 1,7 & 1,2 & 16,3 & 21,1 & 19,8 & 11,2 \\
\hline E. kalaharicus & 2,2 & 3,7 & 1,3 & 2,4 & 2,4 & 4,2 & 14,4 & 7,3 & 4,6 & 一 & 37,9 & 27,6 & 43,6 & 12,1 & 23,4 & 17,3 & 5,1 & 0,4 & 0,4 & 8,8 \\
\hline $\begin{array}{c}\text { E. caudatum } f \text {. } \\
\text { dubardi }\end{array}$ & - & 0,5 & - & 3,2 & 2,5 & 3,3 & 18,4 & 9,2 & 11,9 & - & 27,0 & 13,7 & 19,9 & 4,1 & 13,9 & 30,2 & 2,8 & 0,4 & 0,4 & 4,7 \\
\hline E. lucii & 13,7 & 14,4 & 8,9 & 8,4 & 4,1 & 13,0 & 3,6 & 14,6 & 18,3 & - & 10,3 & 7,2 & 5,7 & 3,6 & 7,4 & 6,2 & 3,7 & 0,4 & - & 3,7 \\
\hline $\begin{array}{l}\text { E. antero - } \\
\quad \text { nucleatum }\end{array}$ & 0,4 & 3,7 & 3,5 & 0,4 & 3,3 & 0,5 & 3,6 & 1,4 & 0,9 & - & 0,3 & 1,4 & 1,4 & 7,6 & 0,8 & 3,3 & 1,4 & 0,4 & - & 1,9 \\
\hline E. fyferi & 1,3 & 1,4 & 1,3 & 1,6 & 2,9 & 2,8 & - & 0,4 & 0,9 & - & 0,9 & - & - & 1,4 & 1,2 & 1,2 & 2,3 & 3,4 & 4,5 & 3,7 \\
\hline E. bovis & - & - & - & - & - & - & 9,0 & 0,4 & - & - & - & 0,9 & 0,4 & - & - & 0,4 & - & - & - & - \\
\hline $\begin{array}{l}\text { E. longi- } \\
\quad \text { nucleatum }\end{array}$ & - & - & - & - & - & - & - & - & - & - & 0,3 & - & - & - & - & - & - & - & - & - \\
\hline
\end{tabular}


Table 3

Dominance status of ciliate protozoa found in different areas

\begin{tabular}{|c|c|c|c|c|c|}
\hline \multirow[t]{2}{*}{ Status } & \multicolumn{5}{|c|}{ Area } \\
\hline & Angola & Karasburg & Kalahari & Ermelo & Graaff Reinet \\
\hline Dominant & E. parvum & E. parvum & $\begin{array}{c}\text { E. parvum } \\
\text { E. kalaha- } \\
\text { ricus }\end{array}$ & E. parvum & E. parvum \\
\hline $\begin{array}{l}\text { Sub- } \\
\text { dominant }\end{array}$ & $\begin{array}{l}\text { E. dubardi } \\
\text { E. alces } \\
\text { E. lucii }\end{array}$ & $\begin{array}{l}\text { E. dubardi } \\
\text { E. lucii }\end{array}$ & $\begin{array}{l}\text { E. dubardi } \\
\text { E. alces } \\
\text { E. caudatum } \\
\text { E. lucii }\end{array}$ & E. alces & $\begin{array}{l}\text { E. dubardi } \\
\text { E. alces } \\
\text { E. kalaharicus } \\
\text { E. caudatum }\end{array}$ \\
\hline $\begin{array}{l}\text { Present in } \\
\text { low } \\
\text { numbers }\end{array}$ & $\begin{array}{c}\text { E. kalaha- } \\
\text { ricus } \\
\text { E. antero- } \\
\text { nucleatum } \\
\text { E. fyferi }\end{array}$ & \begin{tabular}{|l|} 
E. caudatum \\
\\
E. kalaha- \\
$\quad$ ricus \\
E. antero- \\
$\quad$ nucleatum \\
E. fyferi \\
E. alces
\end{tabular} & $\begin{array}{l}\text { E. fyferi } \\
\begin{array}{c}\text { E. antero- } \\
\text { nucleatum } \\
\text { E. bovrs }\end{array}\end{array}$ & \begin{tabular}{|l|} 
E. dubardi \\
\\
E. kalaha- \\
$\quad$ ricus \\
E. caudatum \\
E. antero- \\
$\quad \quad$ nucleatum \\
E. fyferi \\
E. lucii
\end{tabular} & $\begin{array}{l}\text { E. lucii } \\
\text { E. antero- } \\
\text { nucleatum } \\
\text { E. fyferi } \\
\\
\end{array}$ \\
\hline Absent & $\begin{array}{l}\text { E. caudatum } \\
\text { E. bovis }\end{array}$ & E. bovis & & E. bovis & E. bovis \\
\hline
\end{tabular}

\section{Food Composition}

The composition of the food ingested by the host animal plays an important role in the population structure and numbers of the rumen ciliate fauna.

Diets rich in protein have been shown to increase the ciliate populations considerably. Similarly Entodinium becomes particularly numerous in ruminants fed large quantities of grain because of their ability to utilize starch (Hungate 1966). According to Westerling (1970), this is because Entodinium is generally believed to specialize on starch for its supply of energy. However, Hungate (1966) cites Sugden (1953) as stating that some very small species of Entodinium are not able to utilize starch to a significan degree, due to their inability to ingest the large starch grains.

The ability of ciliates to ingest and digest cellulose has been shown (Hungate 1966) but their importance in cellulose digestion is not known. Hungate (1966) cites a number of authors who believe that this is principally the function of rumen bacteria.

The entodiniomorphs generally appear to have a very limited ability to utilize soluble substrates (Abou Akkada and Howard 1960). Thus 
sugars should have little effect on the population structure where only Entodinia are present.

Preservation of rumen digesta in formalin does not affect the analyses of it significantly as the residue on ignition of a 35\% formaldehyde solution consists of:
Sulphates
$0,002 \%$
Free acid
$0,03 \%$
Chloride
$0,0001 \%$
Heavy metals
$0,0005 \%$
Iron
$0,00015 \%$

This gives a total of $0,03675 \%$ inorganic substance which will be shown in the ash determination. This is, however, so small that it can be ignored.

The results of the rumen digesta analyses found in this study are given in Table 4.

Table 4

Analyses of rumen digesta from all the springbok in each area given as a percentage of the total food composition

\begin{tabular}{|c|c|c|c|c|c|}
\hline \multirow[t]{2}{*}{ Food } & \multicolumn{5}{|c|}{ Area } \\
\hline & Angola & Karasburg & Kalahari & Ermelo & $\begin{array}{l}\text { Graaff } \\
\text { Reinet }\end{array}$ \\
\hline Protein & 14,30 & 16,00 & 16,22 & 13,31 & 15,71 \\
\hline Fibre & 25,33 & 34,88 & 34,89 & 29,43 & 29,61 \\
\hline Ash & 15,98 & 17,82 & 16,07 & 17,59 & 10,55 \\
\hline Starch & 0,84 & 0,85 & 0,75 & 0,61 & 0,79 \\
\hline
\end{tabular}

\section{Discussion}

The total numbers of rumen ciliates in a host show a good correlation with the protein content of the food. Although the differences in protein content of samples from different areas were not great, the lower protein diet of the springbok from Ermelo coincides with a marked drop in numbers. Similarly, the highest protein content, found in the Kalahari, coincides with the highest numbers. This concurs with the observations of earlier workers (Hungate 1966; Westerling 1970).

The ash content, or inorganic component of the food shows a slight negative correlation with the numbers. This is most evident in Ermelo and Graaff Reinet.

Fibre content does not appear to be correlated with numbers at all as it shows a positive correlation with the drop in numbers in Ermelo but a negative correlation in Angola. This is consistant with the idea 
that the digestion of cellulose is principally the function of the rumen bacteria. With respect to this Hungate (1966) states, "Entodinium, with the possible exception of Entodinium bursa, does not digest cellulose, but has been observed to ingest it."

Although some correlation has been made in the past between the food composition and the genera present, little or nothing is known about its connection with the species variation. It has, however, been evident in this study that there is a connection between species composition and protein availability. In the relatively low protein diet of the springbok E. parvum dominates all populations with sub-dominant species forming low percentages of the population. This is particularly evident in Ermelo where the lowest protein values were found coinciding with an average $E$. parvum population of 71 per cent. In Angola the protein value is slightly higher and $E$. parvum forms $64,5 \%$ of the population. In Graaff Reinet and Karasburg which have respectively higher protein values $60 \%$ and $57 \%$ of the ciliate population's consisted of $E$. parvum. The highest protein values were found from the Kalahari and here E. parvum performed about $38 \%$ of the population. population.

This suggests that E. parvum is at an ecological advantage in a lowprotein environment while those species which were sub-dominant or only present in low numbers, began to compete successfully with it as protein availability increased. This possibility must at this stage remain speculative and requires further intensive study to be verified.

Both Dogiel (1927) and Westerling (1970) found that the ciliate fauna in the reindeer Rangifer tarandus consists largely of species which are specific to this host. This species specificity is not evident in the springbok as most species have been identified in other ruminants. This is because there is a decisive dietical difference between the reindeers diet and that of other ruminants. The bulk of the reindeer diet is lichen, the carbohydrates of which are comparitively unique. The diet of the springbok, on the other hand, is of a far more general nature.

\section{Acknowledgements}

We thank Prof. J. D. Skinner and Mr. T. Robinson for collecting some of the samples and the National Parks Board of Trustees and the owners of private nature reserves for their kind cooperation in obtaining the material.

\section{REFERENCES}

ABOU AKKADA, A. R. and B. H. HOWARD 1960. The biochemistry of rumen protozoa, 3. The carbohydrate metabolism of Entodinium. Biochem.J. 76:445-551.

DEHORITY, B. A. 1974. Rumen ciliate fauna of Alaskan Moose (Alces americana), Musk-ox (Ovibos moschatus) and Dall Mountain Sheep (Ovis dalli). J. Protozool. $21: 26-32$. 
DOGIEL, V. A. 1927. Monographie der Familie Ophryoscolecidae. Arch. Protistenk. 59:1-288.

HUNGATE, R. E. 1966. The rumen and its microbes. New York: Academic Pr.

PEARSON, H. A. 1965. Rumen organisms in White-Tailed Deer from South Texas. J. Wildl. Mgmt. 29:493-496.

VAN HOVEN, W. 1974. Ciliate protozoa and aspects of the nutrition of the hippopotamus in the Kruger National Park. .S. Afr. J. Sci. 70:107-109.

VAN HOVEN, W. 1975. Rumen ciliate fauna of the Tsessebe (Damaliscus lunatus (unatus) in South Africa. J. Protozool. 22:457-462.

WESTERLING, B. 1970. Rumen ciliate fauna of semi-domestic Reindeer (Rangifer tarandus L) in Finland: Composition, volume and some seasonal variations. Acta Zool. Fennica. 127:1-75. 